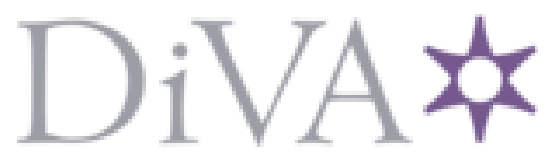

http://www.diva-portal.org

This is the published version of a paper published in Vård $i$ Norden.

Citation for the original published paper (version of record):

Ledin, A., Olsen, L., Josefsson, K. (2011)

Sjuksköterskors syn på svårigheter i telefonrådgivning: En litteraturstudie.

Vård i Norden, 100(31): 11-18

Access to the published version may require subscription.

N.B. When citing this work, cite the original published paper.

Permanent link to this version:

http://urn.kb.se/resolve?urn=urn:nbn:se:mdh:diva-26705 


\title{
Sjuksköterskors syn på svårigheter i telefonrådgivning: En litteraturstudie
}

\begin{abstract}
Annica Ledin, Leg. sjuksköterska, distriktssköterska, magister i omvårdnad, Lisbet Olsen, Leg. sjuksköterska, distriktssköterska, magister i omvårdnad, Karin Josefsson, Leg. sjuksköterska, Medicine Doktor i Klinisk Äldreforskning
\end{abstract}

DIFFICULTIES IN TELEPHONE ADVICE AS PERCEIVED BY REGISTERED NURSES: A LITERATURE STUDY

\section{ABSTRACT}

Aim: To deepen the knowledge of difficulties in registered nurses telephone advice and identify possibilities to master these. Background: Telephone advice increases the accessibility to health care and the streamlined work at primary health care centres. The goal of telephone advice nursing is to give a correct advice, adapted to the caller's situation, in order to reach correct care level. However, nurses' telephone advice includes risks for misjudgement and may risk the patient safety.

Methods: A systematic and manual literature study was used in CINAHL and Pubmed. A total of 38 studies were identified and 13 articles were screened in full text.

Findings: Nurses' had difficulties in telephone advice in following areas: computerized decision aids, non-visual communication, third-part communication, limited resources, the nurses'vulnerability, genus and ethnicity, and also ethical questions.

Conclusion: Nurses perceived difficulties in telephone advice. They should take part in the development of computerized decision support and receive continuous training in communication skills. Nurses' telephone advice should be facilitated by the existence of an open climate at the workplace, to discuss and to reflect on difficulties, in order to reach patient safety.

KEY WORDS: Registered nurse, telenursing, telephone consultation, literature study.

\section{BAKGRUND}

\section{Telefonrådgivning}

Telefonrådgivning ingår i sjuksköterskan arbetsuppgifter och är en växande del i professionen (1-4). Målet med telefonrådgivning är att uppringaren ska få råd anpassande efter dennes situation och att uppringaren når rätt vårdnivå (5-9). Många av samtalen rings inte av den som behöver råd eller vård, utan det är oftast någon annan, en kvinnlig familjemedlem (5). Därför definieras i denna studie, uppringaren, som den personen som ringer rådgivningen.

\section{Telefonrådgivning i Sverige}

Det går att ringa för råd till de flesta av landets landstingsanslutna och privata vårdcentraler samt till sjukvårdsrådgivningen 1177, som är en samordning av Sveriges regioners och Landstingens sjukvårdsrådgivningar. Till det nationella kortnumret, 1177, kan allmänheten ringa dygnet runt för rådgivning av sjuksköterskor. Allmänheten kan också besöka deras hemsida för råd om egenvård (10). Sjukvårdsrådgivningen 1177 tar emot cirka 400000 samtal i månaden och hemsidan har cirka en miljon besökare per månad. Sjuksköterskor i 1177 har tillgång till datoriserat beslutsstöd. De kan även vid behov konsultera primär- eller specialistvårds instanser. Sjuksköterskorna upprättar journal på uppringaren och dokumenterar anamnes och beslut som tagits. Sjuksköterskorna har möjlighet $\mathrm{i}$ vissa landsting att boka tider på jourenheter och i vissa fall även på specialistmottagningar (11).

Vårdcentraler inom primärvården kan ha ett telefonuppringningssystem, Flexi Tid. Det innebär att en automatisk telefonsvarare svarar när uppringaren ringer vårdcentralen som ber uppringaren att knappa in sitt telefonnummer och personnummer. Uppringaren får en bestämd tid då sjuksköterskan ringer upp (12). Sjuksköterskor bedömer vilken vårdnivå som vårdsökande är i behov av och har möjlighet att boka tid för uppringaren på läkarmottagning, distriktssköterskemottagning eller hänvisar till andra vårdinstanser. Datorbaserat beslutsstöd ger sjuksköterskor tillgång till information och stöd i deras beslut. Men långt ifrån alla vårdcentraler har ett datoriserat beslutstöd (13).

\section{Telefonrådgivning - ett vårdmöte}

Telefonrådgivning innebär ett möte mellan uppringaren och sjuksköterskan. Mötet är ofta kort. För att mötet ska vara professionellt är det viktigt att skapa en förtroendefull relation och god kontakt (9). Valanis m.fl (14) menade att om uppringaren ska bli nöjd med telefonrådgivningen, är det viktigast att få goda råd, möta en trevlig och sympatisk sjuksköterska och snabbt få en läkartid inbokad (14). Sjuksköterskor i telefonrådgivning får frågor som varierar brett och mer än 60 procent vill diskutera medicinska problem (5). Det innebär att stora krav ställs på sjuksköterskors kompetens. Sjuksköterskor ska som rådgivare lösa både små och stora problem, som att ge egenvårdsråd, lugna osäkra människor och dämpa oro och ångest (7).

Flera författare har beskrivit mötet $i$ telefonrådgivning mellan uppringaren och sjuksköterska och de beskriver samtalsprocessen något olika $(5,6$, 9). Den modell som ligger till grund för $1177 \mathrm{~s}$ samtalsprocess har fem faser och har utvecklats av Runius (15). Modellen ska stödja sjuksköterskan genom samtalet och säkerställa den medicinska bedömningen via telefon. I öppningsfasen betonas vikten av att samtalet inleds på ett sätt som gör att uppringaren känner sig lyssnad på och att sjuksköterskans röst förmedlar trygghet och genuint intresse. Lyssnandefasen karaktäriseras av förutsättningslöst lyssnade och sammanfattningar av samtalet. Sjuksköterskan ska även lyssna till det som inte sägs med ord och tolka det icke-verbala t.ex. ansträngd andning, rädsla, förringelse av rädsla $\mathrm{mm}$. I analysoch bedömningsfasen ställer sjuksköterskan relevanta frågor och lyssnar vidare på uppringarens svar. Det är viktigt att bekräfta och sammanfatta uppgifter och känslor som förmedlas så att samförstånd inträder. I motivations- och åtgärdsfasen presenterar och förklarar sjuksköterskan sin bedömning och ger information och råd. I avslutningsfasen görs en överenskommelse, där sjuksköterskan informerar uppringaren om att kontakta vården igen vid nya symtom eller om symtomen förvärras $(10,15)$. 


\section{Stress $\mathrm{i}$ arbetslivet}

Karasek och Theorell (16) har utarbetat krav-kontroll-stöd-modellen. Modellen mäter stress i arbetslivet genom de krav och den egenkontroll som arbetstagaren upplever, samt graden av socialt stöd. Krav kan vara kvantitativa eller kvalitativa (känslomässiga), som arbetskrav, tidspress och motstridiga krav. Modellen menar att psykologisk ansträngning kommer från den gemensamma effekten av krav. Med egenkontroll menas arbetstagarens inflytande i beslut, som kontroll över arbetssituationen och kompetensutnyttjande, det vill säga hur arbetstagarens kompetens tas till vara och utvecklas (kunskapskontroll). Definitionen på socialt stöd inkluderar att arbetskamrater och arbetsledare visar positiv respons, hjälper och visar personligt intresse.

Modellen är ofta använd i studier av arbetsmiljön inom sjuksköterskors arbetsområde och bidrar till att förstå sambandet mellan arbetsorganisationen, upplevd stress och hälsa (17). Karasek och Theorell (16) menar att det är främst balansen mellan arbetsrelaterade krav och arbetstagarens egenkontroll som är avgörande för upplevd stress och hälsa. När arbetstagaren känner att arbetet kan utföras med en känsla av hög egenkontroll och utrymme att använda sina färdigheter och kunskaper, leder det till en stimulerande arbetssituation. Upplever däremot arbetstagaren att arbetet innebär höga krav tillsammans med låg egenkontroll kan det skapa en spänd arbetssituation, som på sikt kan leda till arbetsrelaterad stress och ohälsosamma effekter. Socialt stöd från arbetskamrater och arbetsledning kan dock ge en skyddande effekt mot den arbetsrelaterade stressen.

Sammantaget, litteraturen ovan visar att det finns risk för felbedömningar i sjuksköterskors telefonrådgivning, som kan äventyra patientsäkerheten. En hållbar arbetssituation är avgörande för sjuksköterskans hälsa. Därför är det viktigt att fördjupa kunskaperna om de svårigheter som finns inbyggda i sjuksköterskans telefonrådgivningsarbete och identifiera möjligheter att bemästra dessa.

\section{SYFTE}

Syftet var att fördjupa kunskapen om de svårigheter som finns inbyggda i sjuksköterskans telefonrådgivningsarbete och identifiera möjligheter att bemästra dessa.

\section{METOD}

Systematisk och manuell litteraturstudie, inspirerat av Polit \& Becks «Flow of tasks in a literature review» (18, s. 108), se Figur. Genom att ta del av tidigare forskningsresultat erhölls en sammanhängande överblick av området.

\section{Sökstrategi}

Systematisk litteratursökning gjordes i PubMed och Cinahl. Sökorden som användes var: telephone advice, telephone counsel*, nurs*, care, primary health care, nhs direct, experience*, apprehen*, perception, view*, problem*, difficult*, obstacl*. En grundsökning inleddes med orden: (telephone advice or telephone counsel*) AND (nurs* or care). Därefter gjordes sökningar med tre kombinationer med de övriga sökorden i de båda databaserna.

\section{Urval}

Litteratursökningen begränsades till 1999-2009. Studierna skulle vara vetenskapliga publikationer samt skrivna på engelska och svenska. Andra inklusionskriterier var att sjuksköterskorna skulle arbeta med telefonrådgivning vid vårdcentral och på sjukvårdsrådgivning. Artiklar exkluderades om de var i ett smalt och specifikt område, som psykiatrisk mottagning. Därför att situationen vid specialistinriktad telefonrådgivning berör ett smalt och specifikt område. Urvalen genomfördes av två av författarna (AL, LO) oberoende av varandra. Första urvalet inkluderade 38 artiklar, efter att titlar och sammanfattning lästs. I andra urvalet valdes 24 artiklar, efter sammanfattningarna lästs för att se om de motsvarade studiens syfte. Dessa artiklars referenslistor lästes och från denna manuella sökning inkluderades ytterligare tre artiklar. I tredje urvalet lästes alla artiklar i sin helhet. Därefter valdes 10 artiklar tillsammans med tre artiklar från manuella sökningen. Urvalen var samstämmiga mellan författarna. Totalt 13 artiklar ingår i den här litteraturstudien.

\section{Värdering}

Artiklarna granskades kritiskt och värderades av två bedömare oberoende av varandra (AL, LO) $(19,20)$. Kvalitetsbedömning utfördes enligt kriterier för studier med kvalitativ metod (19). För att klassificera studierna, har antalet frågor som besvarats positivt räknats samman, var artikel för sig (19, s. 96). Båda granskarna var samstämmiga $\mathrm{i}$ bedömningen av att ingen studie var av låg kvalitet.

\section{Analys}

Innehållsanalys genomfördes $(18,20)$ av två av författarna (AL, LO). Först lästes artiklarna för att få en överskådlig bild av innehållet. Därefter läste artiklarna mer noggrant för att få en övergripande förståelse av innehållet, som sammanställdes i en matris (Tabell 1). Nyckelord och nyckelfraser utifrån denna studies syfte markerades med en överstrykningspenna. Därefter placerades nyckelorden och nyckelfraserna som hade gemensamma mönster under samma rubrik och bildade därefter kategorier. Kategorierna och deras innehåll diskuterades utifrån likheter och olikheter med den tredje författaren (KJ) och vid flera seminarier. Vissa ändringar gjordes av kategorierna och visst innehåll fördes över till andra kategorier. Slutligen, analysen identifierade svårigheter i sjuksköterskors telefonrådgivning, som presenterades i sju kategorier: 1) Datoriserat beslutstöd; 2) Icke-visuell kommunikation; 3) Uppgifter i andrahand; 4) Begränsade resurser; 5) Sjuksköterskans utsatthet; 6) Genus och etnicitet: och 7) Etiska frågor.

\section{Figur. Flödesschema för litteraturstudie. Efter Polit och Beck (18, s. 108). \\ die.}

Välja bort

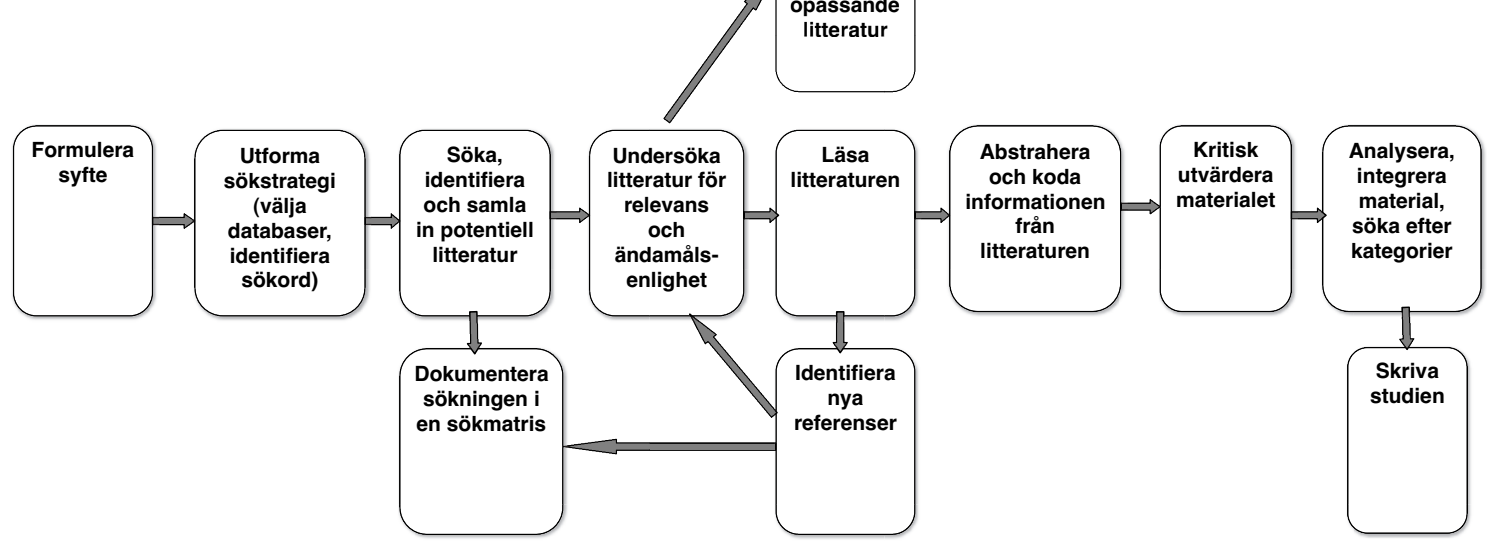




\section{Tabell I. Matris över innehållet i artiklarna}

\begin{tabular}{|c|c|c|c|}
\hline Artikel & Titel & Syfte & Resultat \\
\hline 1 & $\begin{array}{l}\text { Telenurses' experiences } \\
\text { of working with computerized } \\
\text { decision support: supporting, } \\
\text { inhibiting and quality impro- } \\
\text { ving. }\end{array}$ & $\begin{array}{l}\text { Att beskriva sjuksköterskors upp- } \\
\text { levelse av att använda sig av dato- } \\
\text { riserat beslutstöd och hur det kan } \\
\text { ha inflytande på deras arbete. }\end{array}$ & $\begin{array}{l}\text { Sjuksköterskorna uppfattade att datoriserat beslutstöd ibland hämmade } \\
\text { dem i deras yrkesutövning. De uppfattade att mjukvaran var ofullstän- } \\
\text { dig, att den inte överensstämde med sjuksköterskornas egna erfarenhe- } \\
\text { ter. Beslutsstödet uppfattades även vara kontrollerande och en svårig- } \\
\text { het i arbetet. }\end{array}$ \\
\hline 2 & $\begin{array}{l}\text { Knowledge, technology and } \\
\text { nursing: The case of NHS } \\
\text { Direct. }\end{array}$ & $\begin{array}{l}\text { Att beskriva hur interaktionen } \\
\text { mellan sjuksköterskan och } \\
\text { tekniken. }\end{array}$ & $\begin{array}{l}\text { Sjuksköterskorna upplever svårigheter i motsättningen mellan individ- } \\
\text { styrda råd kontra datastandardiseringen. Teknologin är baserad på } \\
\text { ledningens försök att standardisera och kontrollera sjuksköterskans } \\
\text { patientrelation. Sjuksköterskan satte erfarenhet först och såg tekniken } \\
\text { som ett verktyg. }\end{array}$ \\
\hline 3 & $\begin{array}{l}\text { Decision aid software } \\
\text { programs in telenursing: not } \\
\text { used as intended? Experiences } \\
\text { of Swedish telenurses. }\end{array}$ & $\begin{array}{l}\text { Att utforska hur sjuksköterskor } \\
\text { använder datoriserade beslutstöd i } \\
\text { sitt arbete med telefonrådgivning. }\end{array}$ & $\begin{array}{l}\text { Sjuksköterskorna uppfattade att datoriserat beslutstöd var bra för att } \\
\text { utvärdera men inte för att nå ett beslut. De uppfattade att programmen } \\
\text { var inkonsekventa och inte fullständigt uppdaterade framförallt inom } \\
\text { egenvårdråds avsnitten. Organisationen tillät inte så många läkarbesök } \\
\text { innan läkarna blev överbokade. Sjuksköterskorna tyckte att datorstödet } \\
\text { inte var användarvänligt, medicinska facktermer istället för «svenska». }\end{array}$ \\
\hline 4 & $\begin{array}{l}\text { Carer and gatekeeper } \\
\text { - conflicting demands in } \\
\text { nurses experiences of } \\
\text { telephone advisory services. }\end{array}$ & $\begin{array}{l}\text { Att beskriva hur sjuksköterskan } \\
\text { upplever patient mötet vid } \\
\text { telefonrådgivning. }\end{array}$ & $\begin{array}{l}\text { Sjuksköterskorna uppfattade sig både som vårdgivare och grindvakt. } \\
\text { De ska kunna läsa mellan raderna under tidspress. Kände rädsla över } \\
\text { att egenvårdsråden till patienterna kunde missuppfattas. }\end{array}$ \\
\hline 5 & $\begin{array}{l}\text { The faceless encounter: } \\
\text { ethical dilemmas in telephone } \\
\text { nursing. }\end{array}$ & $\begin{array}{l}\text { Att beskriva etiska dilemman, } \\
\mathrm{i} \text { form av motstridiga värderingar, } \\
\text { normer och intressen, som telefon- } \\
\text { rådgivningssköterskan erfar i sitt } \\
\text { arbete. }\end{array}$ & $\begin{array}{l}\text { Sjuksköterskorna uppger svårigheter av etisk karaktär med fem olika } \\
\text { tema: Tema ett: Tala genom tredje part. Tema två: Diskutera personliga } \\
\text { och känsliga problem. Tema tre: Otillräckliga resurser. Tema fyra: Balans } \\
\text { mellan den rådfrågandes informationsbehov och professionellt ansvar. } \\
\text { Tema fem: Skillnader i att bedöma de rådfrågandes tillförlitlighet. }\end{array}$ \\
\hline 6 & $\begin{array}{l}\text { It's easier to talk to a woman. } \\
\text { Aspects of gender in Swedish } \\
\text { telenursing. }\end{array}$ & $\begin{array}{l}\text { Att beskriva och utforska } \\
\text { gender perspektiv inom telefonråd- } \\
\text { givning som svenska telefonråd- } \\
\text { givnings-sjuksköterskor upplever. }\end{array}$ & $\begin{array}{l}\text { Kulturkrockar och språkförbistringar. Uppfattade svårighet } \\
\text { när män i egenskap av familjens överhuvud, ringde och skulle förklara } \\
\text { vad det var för fel på deras fruar eller barn. När unga människor ringde } \\
\text { telefonrådgivningen och inte vågade berätta för sina föräldrar för de } \\
\text { var underordnade i familjen. Att män från andra kulturer var respekt- } \\
\text { lösa mot sjuksköterskorna pga. av att de var kvinnor. }\end{array}$ \\
\hline 8 & $\begin{array}{l}\text { Nurses' views of using } \\
\text { computerized support software } \\
\text { in NHS Direkt. }\end{array}$ & $\begin{array}{l}\text { Att utforska sjuksköterskor syn på } \\
\text { sina roller och det datoriserade } \\
\text { beslutsstöd inom NHS Direct. }\end{array}$ & $\begin{array}{l}\text { Sjuksköterskorna uppgav svårighet med användandet av databeslutstöd } \\
\text { då det behandlade situationerna fyrkantigt. Datorn uppfattades } \\
\text { begränsa sjuksköterskornas kunnande. }\end{array}$ \\
\hline 9 & $\begin{array}{l}\text { Your ears become your eyes: } \\
\text { managing the absence of } \\
\text { visibility in NHS Direct. }\end{array}$ & $\begin{array}{l}\text { Att beskriva sjuksköterskans upp- } \\
\text { levelse av interaktion utan visuell } \\
\text { kontakten vid telefonrådgivning. }\end{array}$ & $\begin{array}{l}\text { Sjuksköterskorna uppfattade att den icke- visuella kontakten var ett } \\
\text { hinder. Svårighet i att bedöma den sjukes tillstånd samt tillförlitlighet. } \\
\text { Att bygga upp ett förtroende var utmanande. }\end{array}$ \\
\hline 10 & $\begin{array}{l}\text { Real nursing? The develop- } \\
\text { ment of telenursing. }\end{array}$ & $\begin{array}{l}\text { Att förstå effekterna av sjuksköter- } \\
\text { skors telefonrådgivning från sjuk- } \\
\text { sköterskornas perspektiv (NHS } \\
\text { direkt) samt att jämföra med sjuk- } \\
\text { sköterskornas syn som arbetar med } \\
\text { traditionell omvårdnad. }\end{array}$ & $\begin{array}{l}\text { Sjuksköterskorna uppfattade att det var stressigt att inte ha den } \\
\text { visuella kontakten och tredje- part kommunikation. Samtal om sjuka } \\
\text { barn och när de rådsökande inte inser behovet av akutvård. Att bemöta } \\
\text { psykiskt sjuka människor var svårt. Saknade brist på uppföljning av de } \\
\text { rådsökande. }\end{array}$ \\
\hline 11 & $\begin{array}{l}\text { Nurses' perceptions of } \\
\text { providing advice via a } \\
\text { telephone care line. }\end{array}$ & $\begin{array}{l}\text { Att beskriva hur sjuksköterskor } \\
\text { uppfattar arbetet med telefonråd- } \\
\text { givning. }\end{array}$ & $\begin{array}{l}\text { Sjuksköterskorna uppfattade att de var pressade att ha stor kompetens } \\
\text { och kunskap och att de utsattes för kritik. De var i en riskposition och } \\
\text { ansvaret var stort. }\end{array}$ \\
\hline 12 & $\begin{array}{l}\text { Telephone nurses' experience } \\
\text { of problems with telephone } \\
\text { advice in Sweden. }\end{array}$ & $\begin{array}{l}\text { Att identifiera problem, svårig- } \\
\text { heter och nackdelar som telefon- } \\
\text { sjuksköterskor med varierande } \\
\text { erfarenhet möter inom telefonråd- } \\
\text { givning i Sverige. }\end{array}$ & $\begin{array}{l}\text { Sjuksköterskorna uppfattade problem i sin telefonrådgivning. Proble- } \\
\text { men rangordnades och delades in i tre perspektiv. } 1 \text {. Sjuksköterskeper- } \\
\text { spektiv: tredje parts kommunikation, icke- visuell kommunikation och } \\
\text { att alltid fatta ett beslut. } 2 \text {. Patientperspektiv: språksvårigheter, svårt } \\
\text { att bemöta människor med psykiska problem och att kunna övertala } \\
\text { den rådsökande att de inte behöver någon läkartid. } 3 \text {. Organisations } \\
\text { perspektiv: stressig arbetssituation och resursbrist. }\end{array}$ \\
\hline
\end{tabular}
pplever patient mötet vid telefonrådgivning.

Att beskriva etiska dilemman, A form av motstridiga värderingar, rådgivningssk arbete. gender perspektiv inom telefonrådgivning som svenska telefonrådgivnings-sjuksköterskor upplever.

Att utforska vilken syn sjuksköte skor har på den nya rollen i NHS Direkt i UK.

Att utforska sjuksköterskor syn pa sina roller och det datoriserade

Att beskriva sjuksköterskans upplevelse av interaktion utan visuell Att beskriva hur sjuksköterskor uppfattar arbetet med telefonrådeter och nackdelar som telefonsjuksköterskor med varierande erfarenhet möter inom telefonrådgivning i Sverige.

Att utforska vad sjuksköterskor baserar sina bedömningar på.
Sjuksköterskorna uppfattade att datoriserat beslutstöd ibland hämmade em i deras yrkesutövning. De uppfattade att mjukvaran var ofullstänhet $\mathrm{i}$ arbetet.

Suksköterskorna upplever svårigheter i motsättningen mellan individ-

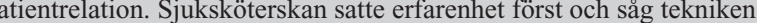

Sjuksköterskorna uppfattade att datoriserat beslutstöd var bra för att men inte for att na ett beslut. De uppfattade att programmen genvårdråds avsnitten. Organisationen tillät inte så många läkarbesök

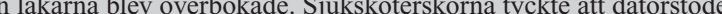

Sjuksköterskorna uppfattade sig både som vårdgivare och grindvakt. De ska kunna läsa mellan raderna under tidspress. Kände rädsla öve att egenvårdsråden till patienterna kunde missuppfattas.

Sjuksköterskorna uppger svårigheter av etisk karaktär med fem olika ema: Tema ett: Tala genom tredje part. Tema två: Diskutera personliga ch känsliga problem. Tema tre: Otillräckliga resurser. Tema fyra: Balan mellan den rådfrågandes informationsbehov och professionellt ansvar. em: Skillnader $i$ att bedöma de rådfrågandes tillförlitlighet. ar underordnade i familjen. Att män från andra kulturer var respekt-

Sjuksköterskorna uppgav svårigheter kopplade till att behålla sin kliniska kompetens. De uppfattade dåligt stöd från ledningen och att man inte hann konferera med kolleger. Fysiska arbetsmiljön var dålig. chema förändringar. Stressigt pga. hög arbetsbelastning och brist på

då det behandlade situationerna fyrkantigt. Datorn uppfattades

Sjuksköterskorna uppfattade att den icke- visuella kontakten var ett hinder. Svårighet i att bedöma den sjukes tillstånd samt tillförlitlighet.

Sjuksköterskorna uppfattade att det var stressigt att inte ha de kontakten och tredje- part kommunikation. Samtal om sjuka psykiskt sjuka människor var svårt. Saknade brist på uppföljning av de

Sjuksköterskorna uppfattade att de var pressade att ha stor kompetens ch kunskap och att de utsattes för kritik. De var i en riskposition och spektiv: tredje parts kommunikation, icke- visuell kommunikation och tt alltid fatta ett beslut. 2. Patientperspektiv: språksvårigheter, svår en rådsökande att de inte behöver någon läkartid. 3. Organisations

Sjuksköterskorna uppfattade osäkerhet att göra bedömningar. 


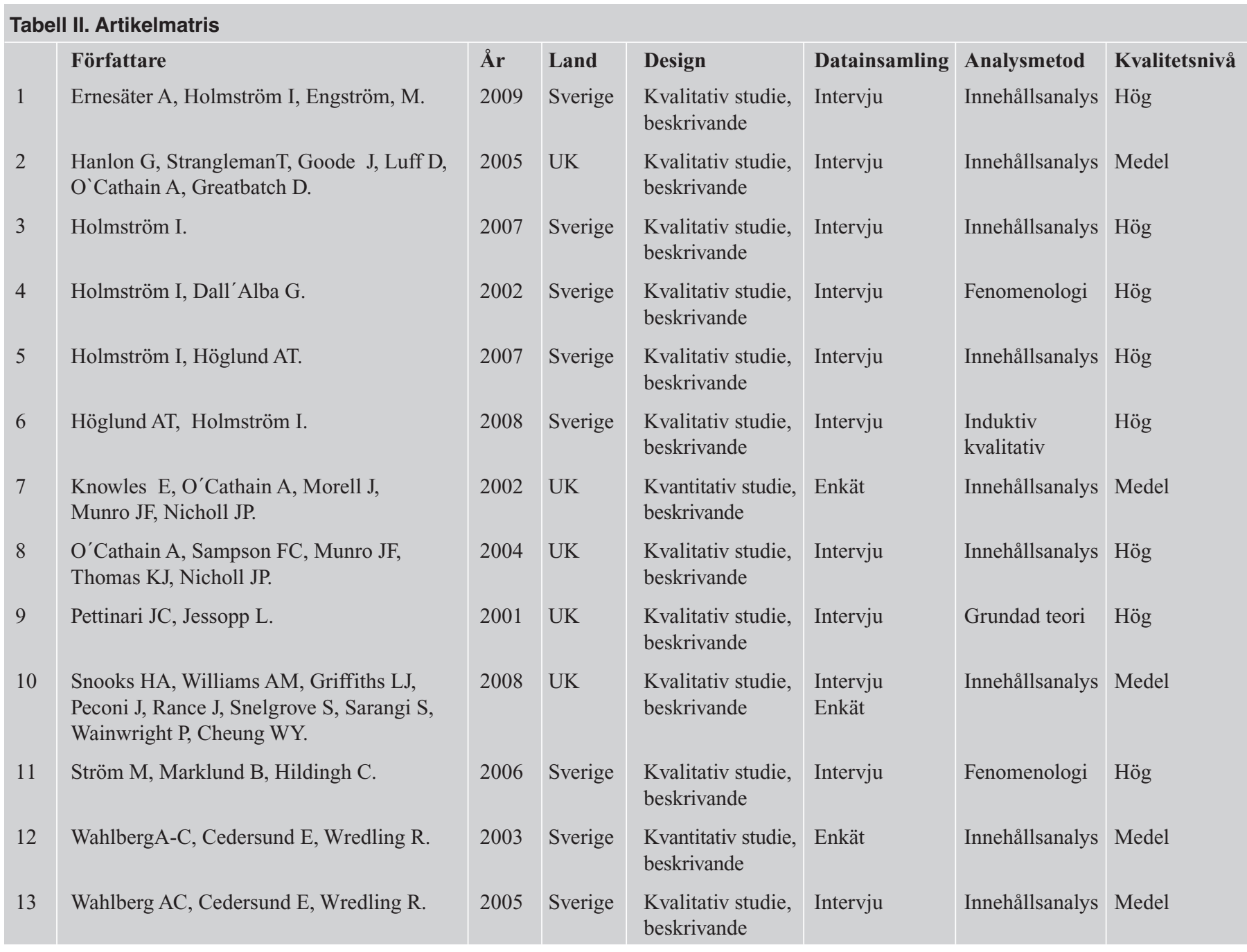

\section{RESULTAT}

Totalt 13 artiklar ingick i den här litteraturstudien, se Tabell 2

\section{Datoriserat beslutstöd}

Datoriserat beslutstöd kunde innebära en svårighet för sjuksköterskornas i telefonrådgivningen $(21,22-24)$. Mjukvaran uppfattades som ofullständig, som inte alltid överensstämde med sjuksköterskornas egna erfarenheter. Sjuksköterskorna ansåg att deras trovärdighet ifrågasattes på grund av att datoriserade beslutstödet gav inkonsekventa svar.

"It says urinary tract problem and incontinence, but...it does not necessarily mean that they are incontinent because they have urinarytract problems - it should not say that - and then it follows as reason for calling...And then you can't delete it.» (24, s. 1079).

Datoriserat beslutstöd uppfattades av sjuksköterskorna som styrande (24). Svårigheten låg i att alla uppringare är unika individer och inte alltid passar in i samma «fack» (25). Sjuksköterskorna ansåg att datoriserat beslutstöd kunde användas som minneshjälp och bedömningsinstrument (23). Däremot brast det datoriserade beslutstödet när sjuksköterskorna hade behov av beslutshjälp. Mjukvaran ansågs inte vara uppdaterad, framför allt för råd om egenvård. Sjuksköterskorna tyckte även att det var svårt med allt för många medicinska termer. De föredrog fler svenska ord istället. Översättningen av medicinska termer tog tid och det fanns risk för missförstånd. Manualer i datoriserade beslutstödet ansågs inte vara användarvänliga. Sjuksköterskorna var oroliga över att upprätthålla sin kliniska kompetens (21). Sjuksköterskorna ansåg att teknologin var baserad på ledningens strävan att standardisera och kontrollera sjuksköterskornas relation till uppringaren (22).

\section{Icke-visuell kommunikation}

Den icke-visuella kommunikationen var en betydande svårighet i sjuksköterskornas telefonrådgivning (26-28). Sjuksköterskorna blev stressade av att inte kunna se uppringaren (27). Det var mycket viktigt att de lyssnade aktivt när uppringaren beskrev sina symtom och besvär.

"It is difficult when you cannot see the patient to make a decision without guidance from for instance body language. A rash, for instance, is impossible over the phone. People describe their symptoms differently.» (27, s. 40).

Den icke-visuella kommunikationen ledde ofta till att sjuksköterskan byggde upp en inre bild av uppringaren och dennes problem. Det kunde leda till att sjuksköterskan drog fel slutsatser och att patientsäkerheten äventyrades, vilket stressade sjuksköterskan.

"It's very much about picture building, which, you know,...can send us to wrong conclusions.» $(28$, s. 636).

Den icke-visuella kommunikationen var en svårighet för sjuksköterskorna i telefonrådgivning (26) . Svårigheterna var att bedöma en sjuk människas tillstånd och uppringarens tillförlitlighet. Sjuksköterskorna ansåg att det var en utmaning för dem att skapa och bygga upp ett förtroende till uppringaren, utan visuell eller fysisk kontakt.

I icke-visuell kommunikation ingår det att uppfatta det icke utsagda i kommunikationen. Att lyssna aktivt och upptäcka det som i fysiska mötet ses med ögonen, som ansiktsuttryck och fysiska förmågor. Sjuksköterskorna likställde problemet med att famla i mörker eller att vara blind. De beskrev att de lyssnade efter röstens tonläge, andningsmönster och hur uppringaren förklarade händelsen (27, 29-30). Räds- 
lan för att missförstå och misstolka information var stor, då det kunde leda till felbedömning.

«I am always afraid of misjudging something important or misinterpreting the patient's signals - that I am not getting the whole picture. There are patients who tell me their symptoms but maybe it is much worse - and the contrary too. It is all about having a sensitive ear...» (29, s. 146).

\section{Uppgifter i andrahand}

Det var vanligt att uppringaren ringde för någon annans räkning, som var i behov av råd eller vård. Sjuksköterskorna uppgav svårigheter att få uppgifter i andrahand, via närstående (27-28, 31-32). De uppfattade att instruktioner eller information kunde förvrängas på grund av att uppgifter gavs i andrahand.

"You ask the (mother) questions and she's interpreting it in her own way... and what she's asking the child is completely different to what you've asked her...» $(28$, s. 635).

\section{Begränsade resurser}

Sjuksköterskorna uppfattade motstridiga krav, genom att både vara vårdgivare och grindvakter i telefonrådgivningen. Grindvaktsfunktionen uppstod till exempel då verksamheten inte tillät så många läkarbesök som sjuksköterskorna ansåg nödvändiga (23, 27-29). De kände sig stressade för att resurserna inte räckte till i den egna verksamheten, vilket tvingade dem att hänvisa uppringaren till akutmottagningen, trots att sjuksköterskorna ansåg det vara fel vårdnivå (27). Motstridiga krav uppfattades då sjuksköterskorna tvingades avsluta samtalen snabbt på grund av stor arbetsbörda, trots att uppringaren behövde mer tid (29). Arbetsbördans tyngd avspeglade sig även i att sjuksköterskorna stressades av att inte hinna följa upp uppringaren (28). Andra begränsade resurser ledde till svårigheter i telefonrådgivningen, som dåligt stöd från ledningen, stress på grund av hög arbetsbelastning, dålig fysisk arbetsmiljö, dåliga arbetstider, snabba schemaförändringar, monotoni och brist på återkoppling (24).

"The management style is poor, senior members of staff are heard to say things 'see what we have to put up with' when describing nurses. The fear of big brother tapping you on the shoulder are very great. People have made an error and are never seen again.» (24, s. 860).

\section{Sjuksköterskans utsatthet}

Sjuksköterskorna kände en utsatthet genom sin frontposition i telefonrådgivningen, vilket uppfattades som höga krav med stor risk att bli kritiserade. Därför ansåg de sig behöva fördjupad kompetens och erfarenhet. "...you are aware that there are demands, after all you are the public face of primary care....» $(33, s .1122)$.

Sjuksköterskorna uttryckte oro över att missförstå situationen och göra felbedömningar, då det kunde leda till ansvarsfall. Rädsla att göra felbedömningar fanns alltid i bakhuvudet på sjuksköterskorna.

"What if the vomiting was not because of gastro-enteritis but ileus instead?» (29, s. 146).

Rädslan växte när uppringaren pratade ett annat språk (29) eller om samtalet var om ett sjukt barn (28-29).

"Children definitely generate a worry...because you've got to rely solely on what the carer is telling you.» $(28, s .634)$.

Sjuksköterskorna kände press att uppdatera sin kunskap, då allmänheten flitigt hämtade information via internet (33). Bemötande av psykiskt sjuka människor var också en svårighet $\mathrm{i}$ telefonrådgivningen (27-28). Det var också svårt att få vissa uppringaren att inse att de var i behov av akutsjukvård (28). Samtidigt som det kunde vara svårt att övertala andra uppringaren i att de inte var i behov av läkarbesök (27).
Framförallt ansåg sjuksköterskorna att det mest utmanande i deras telefonrådgivning, var att de alltid var tvungna att ta beslut.

"The...contents and questions change all the time and it can be difficult to make decisions all the time.» $(27$, s. 40).

\section{Genus och etnicitet}

Situationer kopplade till genus och etnicitet var svårt för sjuksköterskorna (32). De uppfattade att män var mer krävande än kvinnor och att män ibland var respektlösa mot kvinnliga sjuksköterskor.

"These men who call and say 'I want to see a doctor right away, Ineed penicillin because of this and that'. I say 'OK, tell me what's wrong'. And they answer 'that's none of your business, you little smarty. You should give me an appointment right now.» (32, s. 2982).

I vissa kulturer var det mannen som var uppringaren, när det var kvinnan i familjen som hade behov av vård (32). Sjuksköterskorna menade att anledningen till att mannen ringde, var att han var familjens överhuvud. Sjuksköterskorna uppfattade också svårigheter när unga flickor, från familjer som invandrat, inte vågade besöka läkare vid gynekologiska besvär.

... «I advised her to see a doctor but she said she didn't dare to...couldn't do that because then her parents would be accompanying her. And she had had an abortion some time ago and of course they didn't know about that...And she was really devastated and had no one to turn to.» (32, s. 2982).

Det var ibland svårt för sjuksköterskorna att prata med pappor (32). När pappan ringde upp och sjuksköterskan började fråga om symtom på barnet, så räckte pappan ofta över luren till mamman. Pappor bad även sjuksköterskan att upprepa egenvårdsråden till mammorna efter att de pratat klart. Sjuksköterskorna uppgav att det var svårt med språkbarriärer och oroades av att uppringaren och sjuksköterskan skulle misstolka varandra $(27,29,32)$. Sjuksköterskorna menade att det fanns risk för felbedömning när uppringaren hade ett annat modersmål än svenska.

"Immigrants with greater or lesser difficulty in speaking and understanding Swedish - risk of making the wrong decision.» (27, s. 41).

\section{Etiska frågor}

Det fanns etiska svårigheter i telefonrådgivningen. En sjuksköterska kallade telefonrådgivning oetisk (21). Därför att det var osäkert att til fullo veta vem som ringer, trots att uppringaren uppger namn och personnummer. Sjuksköterskorna uppfattade även svårigheter med att dokumentera känsliga saker i journalen.

"Another problem is the documentation in itself... if you refer them for an STD test, or... how much do you actually write in the record about that referral? It can be very sensitive...» (21, s. 1868).

Sjuksköterskorna kände svårigheter med att veta hur mycket information de kunde ge över telefonen. Det var svårt då uppringaren «bara» ringde om egenvårdsråd och sjuksköterskorna tolkade beskrivna symtom som en allvarlig sjukdom. Det var en svårighet för sjuksköterskorna att balansera sin information, för att inte oroa eller stressa uppringaren $\mathrm{i}$ onödan.

"On the one hand, you shouldn't make the patient extremely upset, but on the other hand, you cannot minimize the problem either - it's walking a fine line both ethically and as a fellow human.» (21, s. 1867).

Sjuksköterskorna kände att det var oetiskt hur sjukvården hanterade vissa uppringaren, som människor med psykosociala problem. De uppfattades inte passa in någonstans i sjukvården utan flyttades mellan olika vårdinstanser $(21,31)$. 


\section{DISKUSSION}

\section{Metoddiskussion}

Andra metoder än litteraturstudie kunde använts, som intervju och enkät. Men en systematisk och manuell litteraturstudie användes för få en sammanhängande överblick av området genom att ta del av tidigare forskningsresultat. En litteraturstudie ger även möjlighet att dra nya slutsatser av tidigare studier.

Ambitionen i den här studien har varit att tydligt beskriva metoden, som vilka databaser som användes, sökstrategier, urval med inklusionoch exlusionskriterier, hur artiklarna värderats och hur analysförfarandet gick till. En tydlig beskrivning ökar tillförlitligheten och reproducerbarheten.

För att öka studiens trovärdighet värderades artiklarna. Protokoll användes för att granska och värdera artiklarna, vilket är till hjälp för ett systematiskt arbetssätt (19-20). Endast artiklar från liknande kultur, den västerländska kulturen, har hittats även om det inte var avsikten. Även om kontext skiljer sig mellan länder, kan resultatet från denna studie, vara igenkännbar för sjuksköterskors som arbetar med telefonrådgivningen $\mathrm{i}$ andra länder.

I de studier som ingår i denna studie, kan respektive författares förförståelse om telefonrådgivning riskera systemfel samtidigt som det kan möjliggöra fördjupning av förståelse (23-24, 29, 31-33). Informanternas chefer deltog i urvalet i två studier $(21,25)$. Det kan påverka trovärdigheten. I alla artiklar med innehållsanalys finns en risk för tolkningsfel $\mathrm{i}$ analysen.

Författarna i denna studie har läst artiklarna, var för sig, för att minimera risken för feltolkningar och öka trovärdigheten. Likaså har bildandet av kategorier diskuterats utifrån likheter och olikheter vid seminarier. Vi är medvetna om att visst innehåll av resultatet även kan passa in i andra kategorier. Citat valdes ut, på originalspråket, från artiklarna för att tydliggöra kategoriernas innehåll, det vill säga för att stärka resultatet av analysen. Det kan öka trovärdigheten (20).

\section{Resultatdiskussion}

Resultatet identifierade att sjuksköterskor uppfattade svårigheter i sin telefonrådgivning $(21-25,26-33)$. Svårigheter i arbete kan leda till stress, särskilt med en kombination av låg egenkontroll $(16,17)$. Därför är det viktigt att öka egenkontrollen, genom kompetensutveckling. Det ökar sjuksköterskornas möjlighet att klara av arbetet $(16,17)$.

Sjuksköterskor uppfattade datoriserat beslutstöd som kontrollerande, otillräckligt, missvisande och inte användarvänligt (21-25). Sjuksköterskorna ansåg att datoriserat beslutstöd begränsade deras möjlighet att använda sin omvårdnadskunskap (24). Mjukvaran uppfattades inte vara tillräcklig för egenvårdsråd (23). Resultatet går i linje med Lepännen (4), som menar att införande av ny teknik som datorbaserat beslutsstöd kan begränsa sjuksköterskans arbete. Datoriserat beslutstöd tillkom för att öka säkerheten och ge allmänheten enhetlig information oavsett var de befinner sig i landet (8). IT-system i vården är ofta politiskt attraktivt då de uppfattas som lösningen på de strukturella problem som minskar tillgängligheten i vården (34). Omvårdnad ska ske på personnivå där varje uppringare är unik, som ska bemötas personligt och efter sina förutsättningar (35).

Resultatet ger en bild av, utifrån sjuksköterskornas perspektiv, att datoriserade beslutstödet behöver utvecklas. Vi anser att om datoriserade beslutstöd ska bli patientsäkert bör sjuksköterskorna vara kravställare och vara med att utveckla mjukvaran. Då sjuksköterskan i telefonrådgivning ska stödja uppringarens egenvårdsförmåga (36), anser vi att egenvårdsavsnitten ska vara prioriterat, väl utarbetat och uppdaterade likvärdiga medicinska termer. Att beslutstödet erbjuder sjuksköterskan svenska termer vid sidan om medicinska termer skulle minimera risken för missuppfattningar i översättningsprocessen. Det kan också underlätta sjuksköterskans arbete och minska eventuell stress, genom att deras beslut stöds och känns mindre kravfylld $(16,17)$.

Sjuksköterskorna uppfattade svårigheter med den icke-visuella kommunikationen. Att inte se uppringaren innefattar svårigheter i alla faser i telefonrådgivningen, som att bedöma tillstånd och tillförlitlighet, bygga upp ett förtroende och tolka det icke-utsagda. Att som sjuksköterska i telefonrådgivning inte ha möjlighet att visuellt bedöma uppringaren, uppfattades som att famla i mörker eller att vara blind (29). Att ha uppringaren framför sig och kunna se, känna, lyssna och lukta för att kunna bedöma symtom och avgöra åtgärd är något som saknas för sjuksköterskor i sin telefonrådgivning. Sjuksköterskor i telefonrådgivning har «bara» tillgång till vad uppringaren väljer att informera om eller har kunskap i att informera om. Det är viktigt att bekräfta och sammanfatta uppgifter och känslor som förmedlas i telefonsamtalet så att samförstånd inträder (8). Den icke-visuella kommunikationen kan leda till att sjuksköterskorna bygger en bild av uppringaren och dennes problem i sitt medvetande. Sjuksköterskorna bör då vara medvetna om risken för felbedömning (27-28).

Sjuksköterskorna hanterade den icke-verbala kommunikationen genom aktivt lyssnade, det vill säga genom att läsa mellan raderna, lyssna med ett känsligt öra och försöka uppfatta det outsagda (27-29). Aktivt lyssnande innebär att sjuksköterskan lyssnar och känner igen olika ledtrådar som uppringaren uttrycker och ofta förmedlar via ickeverbal kommunikation (37). Denna förmåga till lyhördhet anser vi bestå av empati, intuition och ett öppet sinne. Enligt Benner (38) utvecklar sjuksköterskan sitt kunnande i mötet mellan erfarenhet, teoretisk kunskap, reflektion och egen personlighet. Vi menar att i en organisation med begränsade resurser finns det för lite tid till reflektion. Därför anser vi att sjuksköterskan i telefonrådgivning behöver organiserad möjlighet till regelbunden utbildning i kommunikationsfärdigheter, som att lyssna aktivt, bemöta, «le med rösten» och informationsutbyte. Att regelbundet lyssna på egna och andra sjuksköterskors samtal borde vara obligatoriskt, för att ge sjuksköterskan möjlighet att reflektera över samtalen och vad som kan förbättras (6). Det kan leda till att sjuksköterskan kan öka förmågan att bedöma och ta relevanta beslut till åtgärd (39). Att klara av kraven på arbetet och att samtidigt ha kontroll över sitt arbete är avgörande för sjuksköterskans hälsa $(16,17)$.

Uppgifter givna $i$ andrahand uppfattades som en svårighet $i$ sjuksköterskornas telefonrådgivning (31). Det kan bli en felaktig tolkning, som kan äventyra patientsäkerheten. Det är av vikt att sjuksköterskorna i första hand får informationen av den människa som är i behov av vård eller råd. Wahlberg m.fl. (27) beskrev orsaker till varför sjuksköterskan får uppgifter i andrahand. Dessa var att den sjuke var för sjuk att ringa själv, inte kunde språket och närstående som tyckte att andra, som små barn, var sjuka. Oftast får sjuksköterskan andrahandsuppgifter från en förälder och sjuksköterskornas rädsla var stor att deras råd skulle misstolkas. Vår rekommendation är att sjuksköterskan i möjligaste mån bör tala med den som är sjuk. Är det inte möjligt, så är det viktigt att sjuksköterskorna i sin bedömning är medvetna om att uppgifterna inte är från primärkällan (6). För att undvika misstolkningar så kan sjuksköterskan upprepa sina råd flera gånger och även be uppringaren att återge råden (29).

Verksamhetens begränsade resurser ledde till att sjuksköterskorna uppfattade svårigheter i telefonrådgivningen (23, 27-29). Svårigheterna bestod i sjuksköterskornas kände motstridiga krav, genom att både vara vårdgivare och grindvakter. Begränsade resurser innebar en hög arbetsbörda, som ledde till tidsbrist. Sjuksköterskorna har makt att besluta om uppringarens tillträde till sjukvården. Sjuksköterskorna har makt över tillgängliga läkartider och sjuksköterskorna står i varje samtal inför hur de ska hantera sin makt. Samtidigt kan sjuksköterskorna känna sig maktlösa, då resurserna var begränsade (5). I denna maktposition eller uppfattning av maktlöshet, är det sjuksköterskornas ansvar att enligt omvårdnadens målsättning balansera situationen så att uppringaren är delaktig, känner sig trygg och upplever respekt (35). Vi är av den uppfattningen att dagens samhälle vill att vården är lättillgänglig, korrekt och säker, och att vården fås snabbt. Men med sjukvårdens begränsade resurser, kan dessa förväntningar vara svåra att upprätthålla. Detta kan leda till att sjuksköterskan i telefonrådgivning får en besvärlig balansgång, mellan begränsade resurser och patientsäkerheten. Här är det viktigt med bra kommunikation mellan sjuksköterskor, kollegor och arbetsledning. Vid höga krav och svåra prioriteringar är det viktigt att sjuksköterskorna får stöd från arbetsledning och arbetskamrater $(16,17)$. Höga krav och avsaknad av stöd kan skapa en spänd arbetssituation, som kan leda till ohälsa hos sjuksköterskorna $(16,17)$.

Sjuksköterskorna kände en utsatthet $\mathrm{i}$ att de hade en frontposition, med risk för kritik och det uppfattades som höga krav (33). Beslutsta- 
gandet var den största svårighet i sjuksköterskornas telefonrådgivning (27). Sjuksköterskorna uttryckte också oro över att göra felbedömningar som kunde leda till ansvarsfall. Som följd av detta kommer vikten av att dokumentera väl och att sjuksköterskorna informerar uppringaren att kontakta vården igen, om symtombilden förvärras eller förändras till det sämre $(10,15)$. Att organisationen är utformad så att den stödjer sjuksköterskornas arbete är en förutsättning för god omvårdnad och att risker undviks (35). Likaså tror vi att ett optimalt datastöd och stöd från kolleger och ledning är en förutsättning för patientsäkerhet. Enligt Karasek och Theorell (16) är det stöd från kollegor och ledning också avgörande för sjuksköterskornas hälsa. Det är viktigt att möjlighet ges till kompetensutveckling, tid för reflektion och uppföljning för att komma förbi svårigheter i sjuksköterskornas telefonrådgivning. Att ha kompetens ger kunskapskontroll, det vill säga att ha kompetens för att klara av arbetsuppgifterna, har en avgörande roll för att sjuksköterskans ska behålla hälsan $(16,17)$.

Sjuksköterskorna uppfattade svårigheter kopplade till genus och etnicitet, som att män var mer krävande och att det var lättare att prata med kvinnor. Sjuksköterskorna uppfattade svårigheter med rådgivningen om uppringaren var från andra kulturer $(27,29)$. Oavsett genus och etnicitet ska varje individ ges goda möjligheter att bli bemötta och behandlade utifrån den individ den är med de unika resurser och behov den har (40). Vi tror inte att uppfattningen av svårigheter att möta människor med annan härkomst endast kan härledas till språkförbistringar, utan att det även handlar om olika vanor och seder eller attityder och värderingar. Även här rekommenderar vi utbildning och utrymme för reflektioner över sjuksköterskornas egna attityder ur genus- och etnicitetsperspektivet. Att utbildas och få möjlighet att reflektera kan ge sjuksköterskans en ökad kunskapskontroll, vilket är utslagsgivande för deras hälsa $(16,17)$.

Sjuksköterskorna uppfattade etiska svårigheter i telefonrådgivning. Svårigheterna rörde sig om en balans mellan dokumentation och informationsutlämnandet. En sjuksköterska ansåg att telefonrådgivning var oetisk, då sjuksköterskan aldrig kunde vara säker på vem som ringer (31). Omvårdnad består av en etisk dimension och sjuksköterskorna har alltid ett etiskt ansvar för sina bedömningar, förslag till åtgärder och uppföljning (41). Likaså har vi diskuterat maktaspekten inom telefonrådgivning. Sjuksköterskorna har kunskap och befogenheter, och uppringaren är i beroendeställning (35). Detta skapar ett möte där yrkesetik är nödvändig. Det är av vikt att arbetsplatsen stödjer etiska diskussioner, för att minska etiska svårigheter och för att telefonrådgivningen genomsyras av god etik. Att få stöd och även öka kompetensen för etiska frågor är oumbärligt för sjuksköterskans hälsa $(16,17)$.

Sammantaget, sjuksköterskorna uppfattade flera svårigheter med telefonrådgivning. Datoriserat beslutstöd behövde utvecklas, framförallt av sjuksköterskor och utifrån omvårdnadsbehovet. Kommunikationssvårigheterna kan underlättas av att sjuksköterskorna får regelbunden utbildning i kommunikationsfärdigheter. De andra svårigheter bör även kunna förbättras av ett öppet klimat på arbetsplatserna, där svårigheterna diskuteras med stöd från arbetsledningen. Denna studie identifierade svårigheter i sjuksköterskors telefonrådgivning och hur dessa kan bemästras. Det kan bidra till att undvika felbedömningar och därmed bidra till hög patientsäkerhet samt en god arbetsmiljö. Det är viktigt att sjuksköterskornas arbete har en balans mellan rimligt höga krav tillsammans med hög egenkontroll och stöd. Det kan hindra skadlig stress, för att istället skapa en stimulerande arbetssituation med hälsosamma effekter.

\section{Slutsats}

Sjuksköterskorna i denna studie uppfattade svårigheter i telefonrådgivning. De bör delta i utvecklingen av datorbaserat beslutsstöd utifrån omvårdnadsbehov. De behöver få kontinuerlig utbildning i kommunikation. Sjuksköterskors telefonrådgivning bör underlättas genom att svårigheter kan diskuteras och reflekteras över på arbetet, för att nå patientsäkerhet.
Godkjent for publisering 29.04.2011

Annica Ledin, Leg. sjuksköterska, distriktssköterska, magister i omvårdnad

Lisbet Olsen, Leg. sjuksköterska, distriktssköterska, magister i omvårdnad

Karin Josefsson, Leg sjuksköterska, Medicine Doktor i Klinisk Äldreforskning

Universitetslektor, Akademin för hälsa, vård och välfärd,

Mälardalens högskola

Vetenskaplig sekreterare, Svensk sjuksköterskeförening

Kommunikation: Karin Josefsson, Akademin för hälsa, vård och välfärd

Mälardalens högskola, Box 325, Se - 63105 Eskilstuna,

karin.josefsson@mdh.se

\section{REFERENSER}

1. Wahlberg AC, Wredling R. Telephone nursing: Calls and caller satisfaction. International Journal of Nursing Practice 1999;5:164-170.

2. Hagan L, Morin D, Lépine R. Evaluation of Telenursing Outcomes: Satisfaction, Self-Care Practices, and Cost Savings. Public Health Nursing 2001;17(4):305-313

3. Bogdan GM, Green JL, Swanson D, Gabow P, Dart RC. (2004). Evaluating patient compliance with nurse advice line recommendations and the impact on healthcare costs. The American Journal of Manage Care 2004;10(8): 534542.

4. Leppänen V. Power in telephone-advice nursing. Nursing Inguiry 2010;17(1):15-26

5. Leppänen V. Telefonsamtal till primärvården. Lund: Studentlitteratur; 2002.

6. Wahlberg AC. Sjuksköterskans telefonrådgivning. Stockholm: Liber AB; 2007.

7. Andersson Bäck M. Conceptions, conflicts and contradictions: in the introduction of a Swedish health call centre. Göteborg: Göteborgs Universitet, Institutionen för arbetsvetenskap; 2008

8. Holmström I. (Red.). Telefonrådgivning inom hälso- och sjukvård. Lund: Studentlitteratur; 2008

9. Marklund B. Symtom, råd, åtgärd: handledning vid patientrådgivning. Lund: Studentlitteratur; 2008

10. Sjukvårdsrådgivningen SVR AB. < www.1177.se > . 2010-05-15.

11. Rahmqvist M, Husberg M. Effekter av sjukvårdsrådgivning per telefon. En analys av rådgivningsverksamheten 1177 i Östergötland och Jämtland. Linköping: Linköping universitets elektroniska press; 2009.

12. Örebro läns landsting, $<$ www.orebroll.se $>$. 2010-05-15.

13. Marklund B, Jansson G. Medicinsk kunskaps- och beslutstöd för telefonrådgivning. In I. Holmström I, red. Telefonrådgivning inom hälso- och sjukvård. Lund: Studentlitteratur; 2008. p. 137-45.

14. Valanis B, Tanner C, Moscato-Randles S, Shapiro S, Izumi S, David M, Keyes C, Mayo A. A model for examining predictors of outcomes of telephone nursing advice. Journal of Nursing Administration 2003;33(2):91-5.

15. Runius L. Sjukvårdsrådgivning-det goda samtalet. In: Holmström I, red. Telefonrådgivning inom hälso- och sjukvård. Lund: Studentlitteratur; 2008. p. 63-77.

16. Karasek R, Theorell, T. Healthy Work: Stress, productivity, and the reconstruction of working life. New York: Basic Books; 1990.

17. Josefsson K. Municipal elderly care: Implications of registered nurses' work situation, education, and competence. Doktorsavhandling, Karolinska institutet, Institutionen för neurobiologi, vårdvetenskap och samhälle; 2006.

18. Polit DF, Beck CT. Nursing research: generating and assessing evidence for nursing practice. Philadelphia: Wolters Kluwer Health/Lippincott Williams \& Wilkins; 2008.

19. Willman A, Stoltz P, Bahtsivani C. Evidensbaserad omvårdnad - en bro mellan forskning och klinisk verksamhet. Lund: Studentlitteratur; 2006.

20. Forsberg C. Wengström Y. Att göra systematiska litteraturstudier: värdering, analys och presentation av omvårdnadsforskning. Stockholm: Natur \& Kultur; 2008 . 
21. Knowles E, O'Cathain A, Morell J, Munro JF, Nicholl JP. NHS Direct and nurses- opportunity or monotony. International Journal of Nursing Studies, 2002;39:857-66.

22. Hanlon G, Strangleman T, Goode J, Luff D, O'Cathain A, Greatbatch D. Knowledge, technology and nursing: The case of NHS Direct. Human relations, 2005;58(2):147-70.

23. Holmström I. Decision aid software programs in telenursing: not used as intended? Experiences of Swedish telenurses. Nursing and Health Sciences, 2007;9:23-8.

24. Ernesäter A, Holmström I, Engström M. Telenurses' experiences of working with computerized decision support: supporting, inhibiting and quality improving. Journal of Advanced Nursing, 2009;65(5):1074-83.

25. O'Cathain A, Sampson FC, Munro JF, Thomas KJ, Nicholl JP. Nurses' views of using computerized support software in NHS Direkt. Journal of Advanced Nursing, 2004;45(3):280-6.

26. Pettinari Johnson CJ, Jessopp L. Your ears become your eyes': managing the absence of visibility in NHS Direct. Journal of Advanced Nursing, 2001;36(5):668-75.

27. Wahlberg AC, Cedersund E, Wredling R. Telephone nurses' experience of problems with telephone advice in Sweden. Journal of Clinical Nursing, 2003;12:37-45.

28. Snooks HA, Williams AM, Griffiths LJ, Peconi J, Rance J, Snelgrove S, Sarangi S, Wainwright P, Cheung WY. Real nursing? The development of telenursing. Journal of Advanced Nursing, 2008;61(6):631-40.

29. Holmström I, Dall'Alba G. Carer and gatekeeper - conflicting demands in nurses' experiences of telephone advisory services. Scandinavian Journal of Caring Sciences, 2002;16:142-48.
30. Wahlberg AC, Cedersund E, Wredling R. Bases for assessments made by telephone advice nurses. Journal of Telemedicine and Telecare, 2005;11:403-7.

31. Holmström I, Höglund AT. The faceless encounter: ethical dilemmas in telephone nursing. Journal of Clinical Nursing, 2007;16:1865-71.

32. Höglund AT, Holmström I. 'It's easier to talk to a woman'. Aspects of gender in Swedish telenursing. Journal of Clinical Nursing, 2008;17:2979-86.

33. Ström M, Marklund B, Hildingh C. Nurses' perceptions of providing advice via a telephone care line. British Journal of Nursing, 2006;15(20):1119-25.

34. May C, Mort M, Williams T, Mair F, Gask L. Health technology assessment in its local contexts: studies of telehealthcare. Social Science \& Medicine, 2003;57:697-710.

35. Svensk sjuksköterskeförening. Svensk sjuksköterskeförening om omvårdnad och god vård. < www.swenurse.se >. 2010-05-15.

36. Svensk sjuksköterskeförening. Kompetensbeskrivning för legitimerad sjuksköterska med specialistsjuksköterskeexamen distriktssköterska. $<$ www.swenurse.se >. 2010-05-15.

37. Lang F, Floyd MR, Beine KL. Clues to Patients' Explanations and Concerns About Their Illnesses. A Call for Active Listening. Archives of Family Medicine, 2000;9(3):222-7.

38. Benner P. Från novis till expert- mästerskap och talang i omvårdnadsarbetet. Lund: Studentlitteratur; 1993.

39. Socialstyrelsen. Kompetensbeskrivning för legitimerad sjuksköterska. $<$ www.sos.se >. 2010-05-15.

40. Svensk sjuksköterskeförening. Särtryck Evidensbaserad vård. $<$ www.swenurse.se $>$. 2010-05-15.

41. International Council of Nurses. $<$ www.icn.ch $>$. 2010-05-15. 